\title{
Effect of Pisha sandstone on water infiltration of different soils on the Chinese Loess Plateau
}

\author{
MA Wenmei ${ }^{1}$, ZHANG Xingchang ${ }^{2 *}$ \\ ${ }^{1}$ College of Resources and Environment, Northwest A\&F University, Yangling 712100, China; \\ ${ }^{2}$ Institute of Soil and Water Conservation, Northwest A\&F University, Yangling 712100, China
}

\begin{abstract}
The infiltration of water into soil is one of the most important soil physical properties that affect soil erosion and the eco-environment, especially in the Pisha sandstone area on the Chinese Loess Plateau. We studied the one-dimensional vertical infiltration of water in three experimental soils, created by mixing Pisha sandstone with sandy soil, irrigation-silted soil, and loessial soil, at mass ratios of $1: 1,1: 2,1: 3,1: 4$, and 1:5. Our objective was to compare water infiltration in the experimental soils and to evaluate the effect of Pisha sandstone on water infiltration. We assessed the effect by measuring soil bulk density (BD), porosity, cumulative infiltration, infiltration rate and saturated hydraulic conductivity $(K s)$. The results showed that Pisha sandstone decreased the infiltration rate and saturated hydraulic conductivity in the three experimental soils. Cumulative infiltration over time was well described by the Philip equation. Sandy soil mixed with the Pisha sandstone at a ratio of 1:3 had the best water-holding capacity. The results provided experimental evidence for the movement of soil water and a technical support for the reconstruction and reclamation of mining soils in the Pisha sandstone area.
\end{abstract}

Keywords: Pisha sandstone; soil structure; saturated hydraulic conductivity; water infiltration

Citation: MA Wenmei, ZHANG Xingchang. 2016. Effect of Pisha sandstone on water infiltration of different soils on the Chinese Loess Plateau. Journal of Arid Land, 8(3): 331-340. doi: 10.1007/s40333-016-0122-8

Large-scale surface mining has been increasing rapidly in the arid and semi-arid regions of China. Surface mining and subsequent reclamation cause soil erosion, water and soil pollution, and other various environmental problems (Mace and Amrhein, 1999; Fu et al., 2000; Stahl et al., 2002; Reynolds and Reddy, 2012). Soil infiltration is recognized as a basic ecological process affecting the runoff of surface water and soil erosion (Ludwig et al., 2005; Michaelides et al., 2009). The infiltration rate in un-mined soil is disturbed during mining, and other soil properties can also be altered. Soil infiltration is directly dependent on the stability of soil structure (Tisdall and Adem, 1986; Herrick et al., 2006), pore structure (Ankeny et al., 1989; Munshower, 1994), bulk density (BD) (Patel and Singh, 1981; Anderson et al., 2008), and saturated hydraulic conductivity $\left(K_{S}\right)$ (Melvis, 2001; Antigha and Essien, 2007). Many studies have focused on the properties of soil infiltration in various homogeneous soils (Bharati et al., 2002; Fiedler et al., 2002; Matula, 2003; Murray and Buttle, 2005). Hydraulic conductivity is one of the most important physical properties determining infiltration rate and other hydrological processes (Gülser and Candemir, 2008). Physical changes to soil can alter the infiltration rates at reclaimed sites, when compared to the infiltration rates at undisturbed sites in the same area (Shrestha et al., 2005).

The Pisha sandstone area, which covers an area of more than $11,000 \mathrm{~km}^{2}$, is located in the

${ }^{*}$ Corresponding author: ZHANG Xingchang (E-mail: zhangxc@ms.iswc.ac.cn)

Received 2015-08-08; revised 2015-10-12; accepted 2015-11-16

(C) Xinjiang Institute of Ecology and Geography, Chinese Academy of Sciences, Science Press and Springer-Verlag Berlin Heidelberg 2016 
contiguous area of the Inner Mongolia autonomous region, and Shaanxi and Shanxi provinces in northwestern China. The Pisha sandstone is a kind of loosely bonded sandstone formed during the Neogene Period and is very hard when dry but becomes loose when wet (Bi et al., 2003; Li and Bi, 2005). This area is plagued by a high rate of erosion of the Pisha sandstone (over 20,000 $\mathrm{t}$ $/\left(\mathrm{km}^{2} \cdot \mathrm{a}\right)$. Controlling the loss of soil and water during the eco-environmental restoration of this area is very difficult. The study of soil infiltration and the prosperities of the mixture of Pisha sandstone with different soils are of paramount importance for improving the use of the Pisha sandstone and developing a more rational method of controlling soil erosion. The hydrogeological properties of Pisha sandstone (Jin et al., 2003), the anti-erosion effect of Pisha sandstone on the physical and chemical properties of soil (Shi et al., 2004; Han et al., 2015), the erosion kinetics, lithologic characteristics (Ye et al., 2004, 2006), and the sediment yield of a small watershed (Wang, 2000) have previously been studied. Quantitative information on the effect of Pisha sandstone on soil infiltration in different types of soils, however, is limited. The purpose of this study was thus to determine the effect of Pisha sandstone on infiltration when mixed with three soils and to determine the best mixture ratio for the reclamation of mining soils.

\section{Materials and methods}

\section{$1.1 \quad$ Sites and soil sampling}

Soils were collected in Jungar Banner in the eastern part of the Ordos Plateau in southwestern Inner Mongolia autonomous region $\left(39^{\circ} 16^{\prime}-40^{\circ} 20^{\prime} \mathrm{N}, 110^{\circ} 05^{\prime}-111^{\circ} 27^{\prime} \mathrm{E}\right)$, and Shaanxi and Shanxi provinces, northwestern China. The Banner has a total area of $769 \mathrm{~km}^{2}$, with a temperate semi-arid continental climate. The annual average temperature ranges from $6.2^{\circ} \mathrm{C}$ to $7.2^{\circ} \mathrm{C}$, and the mean annual precipitation from 379 to $420 \mathrm{~mm}$, over $60 \%$ of which falling from June to August.

Samples from the top $15 \mathrm{~cm}$ of the three most common types of soils in Jungar Banner were collected at different sites: sandy soil from the Longkou region $\left(40^{\circ} 01^{\prime} 19^{\prime \prime} \mathrm{N}, 111^{\circ} 22^{\prime} 07^{\prime \prime} \mathrm{E}\right)$, irrigation-silted soil from near the town of Dalu $\left(40^{\circ} 3^{\prime} 44^{\prime \prime} \mathrm{N}, 111^{\circ} 22^{\prime} 13^{\prime \prime} \mathrm{E}\right)$, and loessial soil from the eastern refuse dump of the Heidaigou opencast coal mine $\left(39^{\circ} 48^{\prime} 10^{\prime \prime} \mathrm{N}, 111^{\circ} 18^{\prime} 29^{\prime \prime} \mathrm{E}\right)$. Pisha sandstone was collected from the Pisha sandstone region near the town of Nuanshui $\left(39^{\circ} 43^{\prime} 01^{\prime \prime} \mathrm{N}\right.$, $\left.110^{\circ} 33^{\prime} 18^{\prime \prime} \mathrm{E}\right)$. Three soil samples were collected randomly in August, 2012 from bare microsites, and the soil chemical and physical properties were determined from the top $10 \mathrm{~cm}$ of the samples.

\subsection{Laboratory analysis}

The collected soils and Pisha sandstone were air-dried, ground and sieved through a 2-mm screen. The mineral and chemical compositions of Pisha sandstone were analyzed by X-ray power diffraction (XRD), and the results are shown in Table 1. The properties of the soils are shown in Table 2. Soil texture was estimated following the National Resources Conservation Service Guide to Texture, adapted from Thien (1979), along with a soil textural triangle to estimate the percentages of sand, silt and clay. The soil particle-size analysis was based on the method proposed by Bouyoucos (1927). Soil saturated water content was measured by the soak test (Klute, 1986). Soil organic matter (SOM) content was determined by the titration method (Walkley and Black, 1934). Soil BD was measured by the gravimetric method (Blake and Hartge, 1986). The total soil porosity was obtained from the BD measurements.

The sandy soil, irrigation-silted soil, and loessial soil were each mixed thoroughly with Pisha sandstone at mass ratios of 50:50,33:67, 25:75, 20:80, and 17:83 (hereafter referred to 1:1, 1:2, $1: 3,1: 4$, and 1:5), with five treatments for each soil and three replicates for each treatment. The mixed experimental soils were packed in columns $7 \mathrm{~cm}$ in diameter and $25 \mathrm{~cm}$ in length in $5-\mathrm{cm}$ increments at the targeted BD. The surface of each $5-\mathrm{cm}$ layer in the columns was roughened to prevent soil stratification. The packed columns were laid for 1-2 days for soil natural subsidence. The BDs of the sandy soil, irrigation-silted soil, loessial soil, and Pisha sandstone were 1.6, 1.4, 1.6 , and $1.4 \mathrm{~g} / \mathrm{cm}^{3}$, respectively. In fact, the BD of Pisha sandstone was $1.55 \mathrm{~g} / \mathrm{cm}^{3}$, and the Pisha 
sandstone, however, swells when wet, which decreased BD. When the bulk density exceeded 1.4 $\mathrm{g} / \mathrm{cm}^{3}$, the Pisha sandstone cannot be packed into the given amount to the column. So we used this $\mathrm{BD}$ in our experiments.

Deionized water at a temperature of $24 \pm 1^{\circ} \mathrm{C}$ was applied to the surface of the columns from Mariotte bottles (height: $50 \mathrm{~cm}$; inner diameter: $7 \mathrm{~cm}$ ) in the infiltration experiments to maintain a constant $4.5-\mathrm{cm}$ head of water (Fig. 1). The whole progress of the wetting front was recorded every $30 \mathrm{~s}$ for the first $6 \mathrm{~min}$, then every $1 \mathrm{~min}$ for the following $20 \mathrm{~min}$, every $2 \mathrm{~min}$ for the next $30 \mathrm{~min}$, every $5 \mathrm{~min}$ for the next $50 \mathrm{~min}$, and every $10 \mathrm{~min}$ until the wetting front disappeared. The outflow was continuously collected for intervals of 30 min with a fraction collector when the wetting front reached the base of the column, until the flow rate became constant. This point determined the saturated hydraulic conductivity (Ks).

Table 1 Mineral and chemical compositions of Pisha sandstone

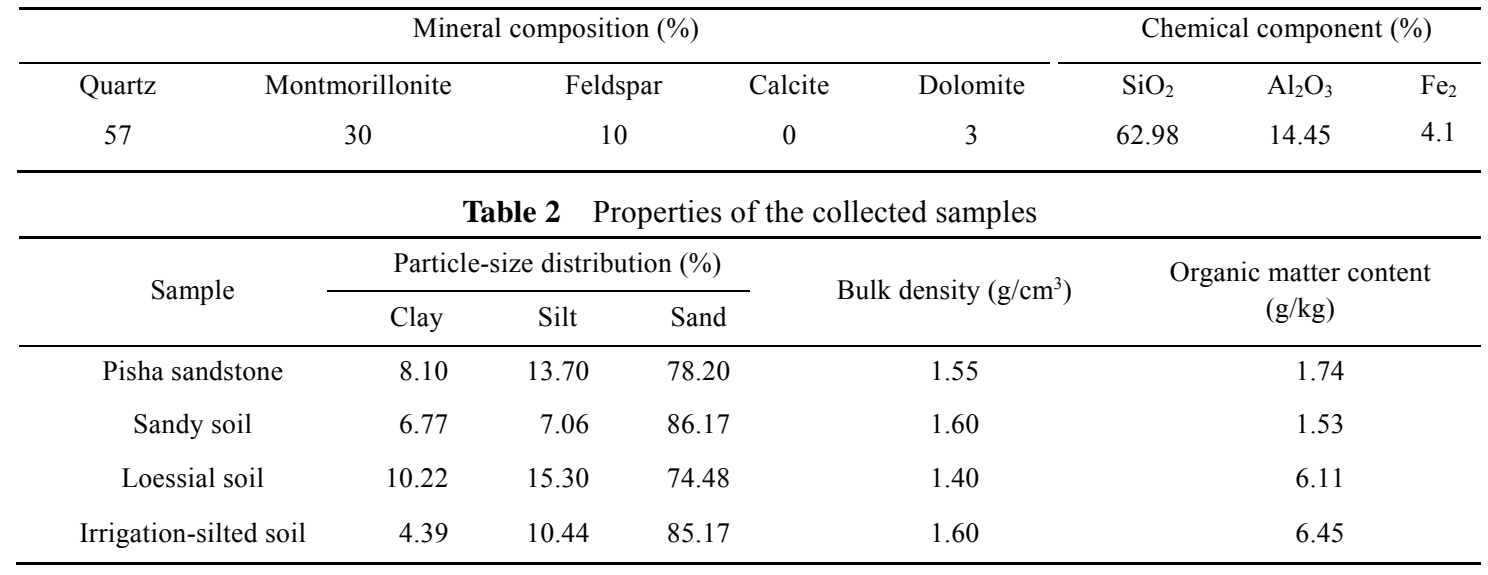

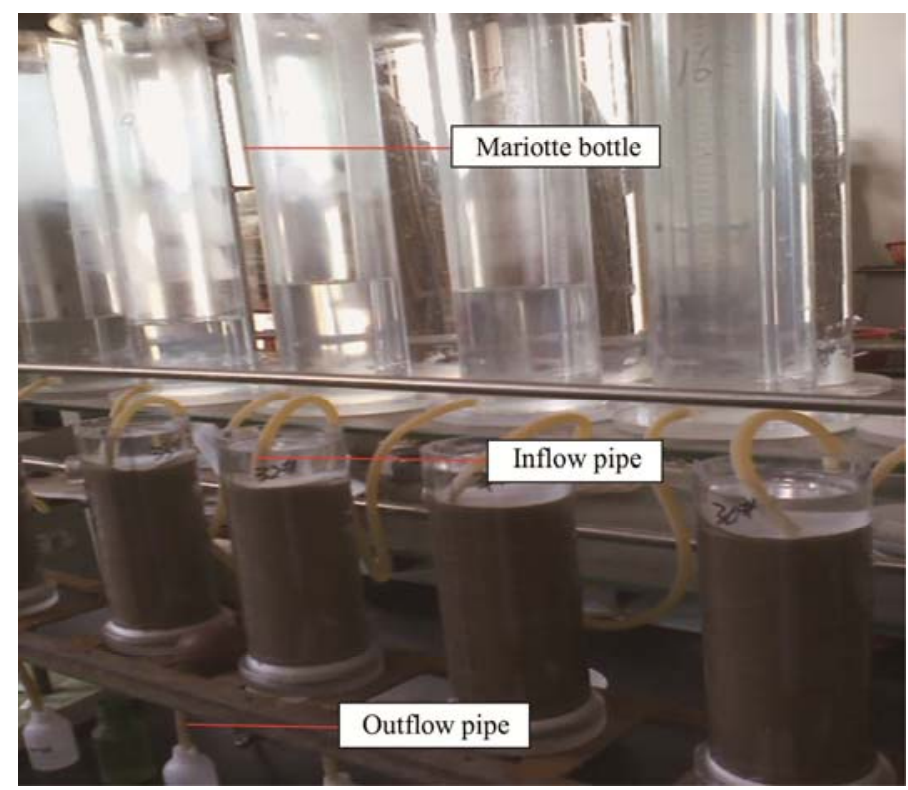

Fig. 1 Experimental setup

\subsection{Modelling}

The Ks of the experimental soils was calculated from the infiltration data according to Darcy's law (Marshall et al., 1996):

$$
K_{s}=\frac{v}{t B} \times \frac{L}{H} .
$$


Where $v / t$ is the volume of water flow per unit time $(\mathrm{mL} / \mathrm{min}), L$ is the length of the soil column $(\mathrm{cm}), B$ is the cross-sectional area of the soil column $\left(\mathrm{cm}^{2}\right)$, and $H$ is the difference in hydrostatic pressure $(\mathrm{cm})$.

The Philip (1957) equation is expressed as:

$$
I=S t^{1 / 2}+A t
$$

Where $I$ is the cumulative infiltration (cm), $t$ is time ( $\min ), S$ is the sorptivity $\left(\mathrm{cm} / \mathrm{min}^{1 / 2}\right)$, and $A$ is the steady-state infiltration rate $(\mathrm{cm} / \mathrm{min})$.

\section{Results and discussion}

\subsection{Soil properties}

The saturated water content, BD, and total porosity in the treatments are presented in Table 3 . The average saturated water contents in the treatments with sandy soil, irrigation-silted soil and loessial soil were $26.98 \%, 25.95 \%$ and $32.83 \%$, respectively. The saturated water content in the 1:1-1:5 sandy soil-Pisha sandstone treatments ranged between $29.01 \%$ and $26.45 \%$. The saturated water content in the 1:1-1:5 irrigation-silted soil-Pisha sandstone treatments ranged between $28.4 \%$ and $24.21 \%$. We found that the saturated water content in these two experimental soils decreased as the content of Pisha sandstone increased. The saturated water content did not vary significantly in the loessial soil-Pisha sandstone treatment.

Table 3 Physical properties of the experimental soils with different proportions of Pisha sandstone

\begin{tabular}{ccccc}
\hline Experimental soil & Treatment & Saturated water content $(\%)$ & Bulk density $\left(\mathrm{g} / \mathrm{cm}^{3}\right)$ & Total porosity $\left(\mathrm{cm}^{3} / \mathrm{cm}^{3}\right)$ \\
\hline Sandy soil & $1: 1$ & $29.01 \pm 0.005$ & $1.49 \pm 0.001$ & $0.448 \pm 0.033$ \\
& $1: 2$ & $27.62 \pm 0.002$ & $1.52 \pm 0.002$ & $0.437 \pm 0.068$ \\
Loessial soil & $1: 3$ & $26.96 \pm 0.003$ & $1.54 \pm 0.001$ & $0.431 \pm 0.019$ \\
& $1: 4$ & $26.90 \pm 0.002$ & $1.55 \pm 0.001$ & $0.427 \pm 0.030$ \\
& $1: 5$ & $26.45 \pm 0.004$ & $1.56 \pm 0.000$ & $0.425 \pm 0.016$ \\
& $1: 2$ & $32.72 \pm 0.001$ & $1.39 \pm 0.001$ & $0.480 \pm 0.044$ \\
Irrigation-silted soil & $1: 3$ & $33.03 \pm 0.005$ & $1.39 \pm 0.002$ & $0.480 \pm 0.054$ \\
& $1: 4$ & $32.98 \pm 0.001$ & $1.40 \pm 0.000$ & $0.479 \pm 0.002$ \\
& $1: 5$ & $32.34 \pm 0.006$ & $1.40 \pm 0.001$ & $0.479 \pm 0.040$ \\
& $1: 2$ & $33.08 \pm 0.013$ & $1.39 \pm 0.013$ & $0.475 \pm 0.025$ \\
& $1: 3$ & $28.40 \pm 0.004$ & $1.49 \pm 0.001$ & $0.449 \pm 0.019$ \\
& $1: 4$ & $26.61 \pm 0.005$ & $1.52 \pm 0.000$ & $0.437 \pm 0.012$ \\
& $1: 5$ & $25.75 \pm 0.003$ & $1.54 \pm 0.000$ & $0.431 \pm 0.005$
\end{tabular}

Pisha sandstone is predominantly composed of coarse sand, but has better water permeability and retention (Qian et al., 1980; Ran et al., 2000; Yang et al., 2013). Loess is also mainly composed of loamy sand (Sun, 2005). Therefore, when the Pisha sandstone is mixed with the loessial soil, the two soils have the same texture, so mixing the two at different ratios changes the soil texture little.

The mean BDs in the sandy soil, irrigation-silted soil and loessial soil were 1.53, 1.54, and 1.40 $\mathrm{g} / \mathrm{cm}^{3}$, respectively (Table 3). The BD increased from $1.49 \mathrm{~g} / \mathrm{cm}^{3}$ for the $1: 1$ treatment to 1.56 $\mathrm{g} / \mathrm{cm}^{3}$ for the $1: 5$ treatment and from $1.49 \mathrm{~g} / \mathrm{cm}^{3}$ for the sandy soil to $1.57 \mathrm{~g} / \mathrm{cm}^{3}$ for the irrigation-silted soil, respectively. BD varied little among the five loessial soil-Pisha sandstone treatments. Soil compaction increases BD (Smith and Woolisher, 1971; Libardi et al., 1982). The 
sand contents of the sandy soil and irrigation-silted soil decreased when mixed with the Pisha sandstone, so the relative proportions of clay and silt increased. These experimental soils became more compacted, and their BD thus increased. Therefore, adding Pisha sandstone to the sandy soil and irrigation-silted soil increased the BD to some extent. Aşkin and Özdemir (2003) suggested that sand content was the most important soil property affecting soil BD. The Pisha sandstone also contained 30\% montmorillonite, whose stable granular structure collapses under the influence of water, and fine particles can clog the connections between soil pores, which would also increase $\mathrm{BD}$ during water infiltration.

Total porosity in the $1: 1-1: 5$ treatments also varied from 0.448 to $0.425 \mathrm{~cm}^{3} / \mathrm{cm}^{3}$ and from 0.449 to $0.422 \mathrm{~cm}^{3} / \mathrm{cm}^{3}$ for the sandy soil and the irrigation-silted soil, respectively. The saturated water content, $\mathrm{BD}$, and total porosity did not changed among the five treatments in the loessial experimental soil. Saturated water content and total porosity were higher in loessial soil than in the sandy soil and the irrigation-silted soil. Total porosity was inversely correlated with BD (Table $3)$. This observation agrees with the finding that $\mathrm{BD}$ is negatively correlated with the number of macro-pores (Gantzer and Anderson, 2002; Kay and Angers, 2002; Chaudhari et al., 2013). Macropore flow rate is more important than clay content and BD for soil matric flow and infiltration process (Shougrakpam et al., 2010). Water flow in clay soil is controlled by the macro-pores to some extent (Ellerbrock and Gerke, 2004; Jarvis et al., 2008). The presence of the Pisha sandstone in the sandy soil and the irrigation-silted soil would thus decrease the area available for water transmission and would create more complex tortuous pathways, while increasing the macroporosity. SOM content is generally assumed to be positively correlated with $K s$, because SOM can stimulate soil aggregation, which lowers $\mathrm{BD}$, and increases porosity and Ks (Lado et al., 2003; Rawls et al., 2005). Increased SOM content generally increase soil water holding capacity and conductivity, largely due to its influence on the distribution of pore spaces (Hudson, 1994). In our study, porosity decreased in the sandy soil and the irrigation-silted soil for the 1:1-1:5 treatments, so we can infer that the water-holding capacity also decreased.

\subsection{Water infiltration}

Smooth cumulative infiltration curves were obtained for the five treatments of the three experimental soils (Fig. 2). In the three soils, with the increase of Pisha sandstone content, the cumulative infiltration increased. The variation of cumulative infiltration and infiltration rate among the three experimental soils showed the same trend. Additionally, during the early stage of the infiltration process, the effect of Pisha sandstone content on cumulative infiltration was less noticeable, but became more pronounced with time as infiltration progressed. Cumulative infiltration did not differ significantly among the 1:1, 1:2, 1:4, and 1:5 treatments. The rate of infiltration was lowest in the 1:3 treatment of the sandy soil.

In order to analyze the cumulative infiltration data, we fitted the experimental data for cumulative infiltration with the Philip infiltration equation (Eq. 2; Table 4). Considering both the downward movement of water due to gravity and advection due to matric forces, the values of the correlation coefficient $R^{2}$ were all above 0.98 , indicating that the equation effectively described the relationship between cumulative infiltration and time during the course of infiltration. Both the sorptivity and steady state infiltration were affected by decreasing Pisha sandstone contents.

Sorptivity determined by the Philip's equation was lower for the 1:3 than for the other treatments. During the infiltration processes, continuous macro-pore systems can promote water flow whereas isolated macro-pores interfere with water movement (Cameira et al., 2003). Furthermore, effective porosity decreased as the Pisha sandstone content increased from treatments 1:1 to 1:5. Infiltration thus decreased due to the presence of macro-pores as the content of Pisha sandstone increased. So when the Pisha sandstone and the sandy soil were mixed at a mass ratio of 1:3, the macro-pore system likely became more continuous, which facilitated the water movement. This showed that a decrease in macro-pores would thereby compensate for water movement. Meanwhile, the variability in soil texture led to different infiltration rates. The 
infiltration rate is higher in the sandy soil than in the irrigation-silted soil and the loessial soil, this may also due to a coarser soil texture, which prevents soil compaction by trampling and provides higher hydraulic conductivity. Moreover, the Pisha sandstone has a high content of montmorillonite (Bouza et al., 2007), which is associated with soil pores and controls the distribution of pore size in sandy soils (Kutílek, 2004).
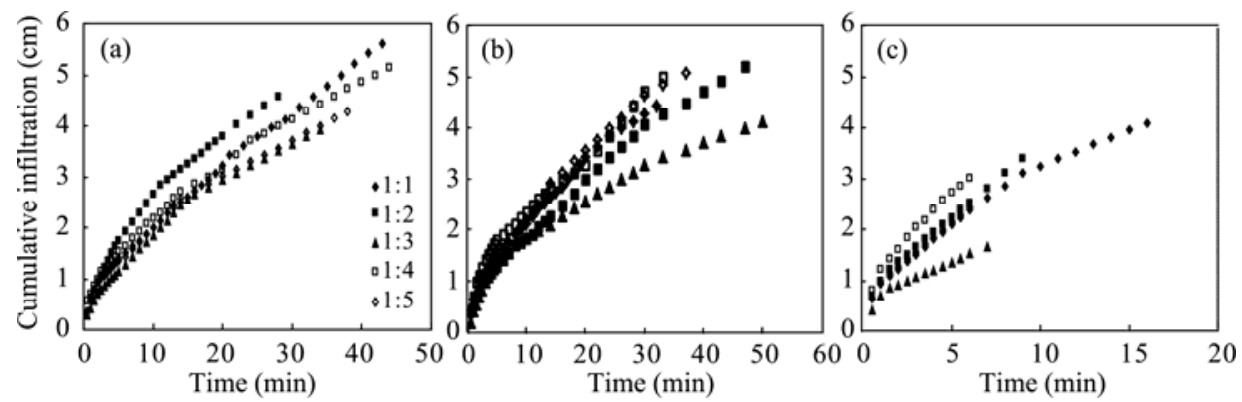

Fig. 2 The relationship between cumulative infiltration and time with different Pisha sandstone contents for the loessial soil (a), the irrigation-silted soil (b), and the sandy soil (c)

Table 4 Parameters of the Philip infiltration equation for the experimental soils with different Pisha sandstone contents

\begin{tabular}{ccccc}
\hline \multirow{2}{*}{ Experimental soil } & Treatment & & Parameter & $R^{2}$ \\
\cline { 3 - 5 } Sandy soil & $1: 1$ & $A(\mathrm{~cm} / \mathrm{min})$ & $S\left(\mathrm{~cm} / \mathrm{min}^{0.5}\right)$ & 0.9951 \\
& $1: 2$ & 0.2250 & 0.4214 & 0.9957 \\
& $1: 3$ & 0.1164 & 0.7192 & 0.9868 \\
Loessial soil & $1: 4$ & 0.0239 & 0.5012 & 0.9983 \\
& $1: 5$ & 0.0799 & 0.9888 & 0.9948 \\
& $1: 1$ & 0.0807 & 0.7351 & 0.9977 \\
& $1: 2$ & 0.0569 & 0.4714 & 0.9958 \\
& $1: 3$ & 0.0908 & 0.6148 & 0.9936 \\
& $1: 4$ & 0.004 & 0.4661 & 0.9987 \\
& $1: 5$ & 0.0212 & 0.6351 & 0.9979 \\
& $1: 1$ & 0.0193 & 0.5776 & 0.997
\end{tabular}

Note: $A$, steady-state infiltration rate; $S$, sorptivity; $R^{2}$, correlation coefficient

Figure 3 shows the infiltration rate as a function of time for the five treatments of the three experimental soils. The average infiltration rates were $0.324,0.393,0.242,0.532$, and 0.402 $\mathrm{cm} / \mathrm{min}$ in treatments $1: 1,1: 2,1: 3,1: 4$ and $1: 5$ of the sandy soil, respectively, $0.169,0.211,0.153$, 0.191 , and $0.171 \mathrm{~cm} / \mathrm{min}$ in treatments $1: 1,1: 2,1: 3,1: 4$ and $1: 5$ of the loessial soil, respectively, and $0.204,0.1590 .1430 .228$ and $0.200 \mathrm{~cm} / \mathrm{min}$ in treatments $1: 1,1: 2,1: 3,1: 4$ and 1:5 of the irrigation-silted soil, respectively. Infiltration rate decreased rapidly over time, and then stabilized. In addition, the effect of Pisha sandstone on infiltration rate became more obvious as infiltration progressed. The infiltration rate was lowest in the 1:3 treatments of all the three experimental soils. 

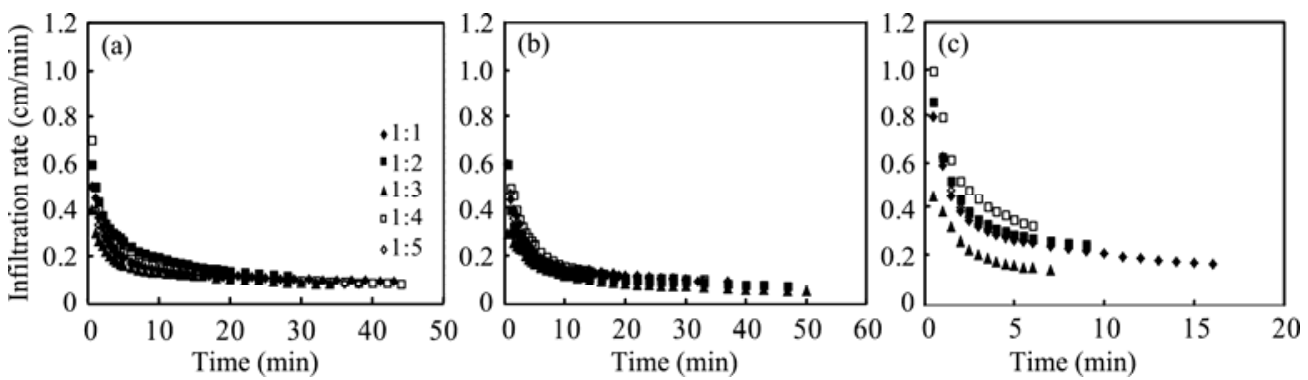

Fig. 3 The relationships between infiltration rate and time with various Pisha sandstone contents for the loessial soil (a), irrigation-silted soil (b), and sandy soil (c)

\subsection{Saturated hydraulic conductivity}

Table 5 shows the effect of soil texture on Ks. Ks was 1- to 6-fold higher in treatments 1:1, 1:2, $1: 4$, and 1:5 than in treatment 1:3 in the three experimental soils. In the same treatment, from the treatment $1: 1$ to $1: 5$, the content of Pisha sandstone increased and the clay content relatively decreased, the values of $K s$ decreased and reached the minimum in the treatment 1:3. In the three experimental soils, the Ks were higher in the sandy soil than in the other two soils, and reached the minimum in the treatment 1:3. Wang et al. (2009) stated that sandy soil will absorb water more rapidly during infiltration processes, and infiltration would be highly correlated with Ks. Meanwhile, macropores greatly increase the rate of infiltration by increasing the volume of storage that must fill the area for matric infiltration (Guebert and Gardner, 2001). In the sandy soil, the flow of macropores and matric water to the soil depends on the hydraulic conductivity. Pisha sandstone has an intermediate content of illite clay with a low shrinkage-swelling capacity that leads to the absence of freeze-thaw process (Senigagliesi and Ferrari, 1993; Taboada et al., 1998; Ni et al., 2008). Therefore, the low ability of loessial soil to form pores could thus not be ameliorated by Pisha sandstone.

Table 5 Saturated hydraulic conductivity $(\mathrm{cm} / \mathrm{min})$ in the treatments of the experimental soils

\begin{tabular}{cccccc}
\hline \multirow{2}{*}{ Experimental soil } & \multicolumn{5}{c}{ Soil treatments with different Pisha sandstone contents } \\
\cline { 2 - 5 } & $1: 1$ & $1: 2$ & $1: 3$ & $1: 4$ & $1: 5$ \\
\hline Sandy soil & 0.2654 & 0.1569 & 0.0295 & 0.0648 & 0.0898 \\
Loessial soil & 0.0830 & 0.1231 & 0.0092 & 0.0150 & 0.0272 \\
Irrigation-silted soil & 0.0382 & 0.0401 & 0.0073 & 0.0214 & 0.0582 \\
\hline
\end{tabular}

\section{Conclusions}

In this study, we mixed Pisha sandstone with three different soils from the Loess Plateau in China to constitute novel experimental soils. The properties of the experimental soils and water infiltration properties were investigated to compare soil water infiltration in the experimental systems and to evaluate the effect of Pisha sandstone on water infiltration. Saturated water contents and total porosity decreased in the sandy soil and the irrigation-silted soil as the Pisha sandstone content increased from 1:1 to $1: 5$ treatment. Saturated water content, BD, and total porosity were not influenced by the Pisha sandstone content in the loessial soil. Total porosity and BD were inversely correlated in the three experimental soils.

Cumulative infiltration and infiltration rate decreased over time as the Pisha sandstone content increased. Both cumulative infiltration and infiltration rate were lowest in the 1:3 treatments. Ks were also lowest in the 1:3 treatments. The Philip equation successfully described the infiltration processes.

This study provides evidence that Pisha sandstone can enhance the movement of water in soils 
on the Loess Plateau. Knowledge of the effect of Pisha sandstone on the infiltration process in the three experimental soils can facilitate the management of land reclamation.

\section{Acknowledgements}

This study was supported by the Key Technology and Demonstration of Damaged Ecosystem Restoration and Reconstruction in Shanxi-Shaanxi-Inner Mongolia Energy Base Location (KZCX2-XB3-13-02). We thank the reviewers for their constructive comments that have greatly improved the quality of this paper.

\section{References}

Anderson J D, Ingram L J, Stahl P D. 2008. Influence of reclamation management practices on microbial biomass carbon and soil organic carbon accumulation in semiarid mined lands of Wyoming. Applied Soil Ecology, 40(2): 387-397.

Ankeny M D, Kaspar T C, Horton R. 1989. Characterization of tillage and traffic effects on unconfined infiltration measurements. Soil Science Society of America Journal, 54(3): 837-840.

Antigha N R B, Essien I E. 2007. The Relationship between infiltration rate and hydraulic conductivity of some soils of Akpabuyo local government area of cross river state -Nigeria. Global Journal of Pure and Applied Science, (6)2: 80-84.

Aşkin T, Özdemir N. 2003. Soil bulk density as related to soil particle size distribution and organic matter content. Poljoprivreda (Osijek), 9(2): 52-55.

Bharati L, Lee K H, Isenhart T M, et al. 2002. Soil-water infiltration under crops, pasture, and established riparian buffer in Midwestern USA. Agroforestry Systems, 56(3): 249-257.

Bi C F, Wang F G, Li G F, et al. 2003. Experiment on sediment retention by plant "flexible dam" in gully in soft rock region. Journal of Sediment Research, (2): 14-25. (in Chinese).

Blake G R, Hartge K H. 1986. Bulk density. In: Klute A. Methods of Soil Analysis: Part 1: Physical and Mineralogical Methods. Monograph Number 9 ( $2^{\text {nd }}$ ed.). Madison: American Society of Agronomy, 363-375.

Bouyoucos G J. 1927. The hydrometer as a new method for the mechanical analysis of soils. Soil Science, 23(5): 343-352.

Bouza P J, Simón M, Aguilar J, et al. 2007. Fibrous-clay mineral formation and soil evolution in Aridisols of northeastern Patagonia, Argentina. Geoderma, 139(1-2): 38-50.

Cameira M R, Fernando R M, Pereira L S. 2003. Soil macropore dynamics affected by tillage and irrigation for a silty loam alluvial soil in southern Portugal. Soil and Tillage Research, 70(2): 131-140.

Chaudhari P R, Ahire D V, Ahire V D, et al. 2013. Soil bulk density as related to soil texture, organic matter content and available total nutrients of Coimbatore Soil. International Journal of Scientific and Research Publications, 3(2): 1-8.

Ellerbrock R H, Gerke H H. 2004. Characterizing organic matter of soil aggregate coatings and biopores by Fourier transform infrared spectroscopy. European Journal of Soil Science, 55(2): 219-228.

Fiedler F R, Frasier G W, Ramirez J A, et al. 2002. Hydrologic response of grasslands: effects of grazing, interactive infiltration, and scale. Journal of Hydrologic Engineering, 7(4): 293-301.

Fu B J, Chen L D, Ma K M, et al. 2000. The relationships between land use and soil conditions in the hilly area of the Loess plateau in northern Shaanxi, China. Catena, 39(1): 69-78.

Gantzer C J, Anderson S H. 2002. Computed tomographic measurement of macroporosity in chisel-disk and no-tillage seedbeds. Soil and Tillage Research, 64(1-2): 101-111.

Guebert M D, Gardner T H. 2001. Macropore flow on a reclaimed surface mine: infiltration and hillslope hydrology. Geomorphology, 39(3-4): 151-169.

Gülser C, Candemir F. 2008. Prediction of saturated hydraulic conductivity using some moisture constants and soil physical properties. In: Proceedings of the BALWOIS. Macedonia, 1-5.

Han J C, Liu Y S, Zhang Y. 2015. Sand stabilization effect of feldspathic sandstone during the fallow period in Mu Us Sandy Land. Journal of Geographical Sciences, 25(4): 428-436.

Herrick J E, Schuman G E, Rango A. 2006. Monitoring ecological processes for restoration projects. Journal for Nature Conservation, 14(3-4): 161-171.

Hudson B D. 1994. Soil organic matter and available water capacity. Journal of Soil and Water Conservation, 49(2): $189-194$.

Jarvis N, Etana A, Stagnitti F. 2008. Water repellency, near-saturated infiltration and preferential solute transport in a macroporous clay soil. Geoderma, 143(3-4): 223-230.

Jin Z P, Miao Z Y, Wang Z W. 2003. Soil Water Conservation and Husbandry Development Research in Pisha Sandstone Area. Zhengzhou: The Yellow River Water Conservancy Press. (in Chinese)

Kay B D, Angers D A. 2002. Soil structure. In: Warrick A W. Soil Physics Companion. Boca Raton, FL: CRC Press, $249-295$. 
Klute A. 1986. Methods of Soil Analysis. Part 1: Physical and Mineralogical Methods, SSSA Book Series 5 (2 $2^{\text {nd }}$ ed.). Madison, WI: SSSA.

Kutílek M. 2004. Soil hydraulic properties as related to soil structure. Soil and Tillage Research, 79(2): $175-184$.

Lado M, Paz A, Ben-Hur M. 2003. Organic matter and aggregate-size interactions in saturated hydraulic conductivity. Soil Science Society of America Journal, 68(1): 234-242.

Li G F, Bi C F. 2005. Develop flexible dams for sediment load reduction of the yellow river. In: Proceedings of the $2^{\text {nd }}$ International Yellow River Forum on Keeping Healthy Life of the River, 126-132. (in Chinese).

Libardi P L, Reichardt K, Jose C, et al. 1982. An approximate method of estimating soil water diffusivity for different soil bulk densities. Water Resources Research, 18(1): 177-181.

Ludwig J A, Wilcox B P, Breshears D D, et al. 2005. Vegetation patches and runoff-erosion as interacting ecohydrological processes in semiarid landscapes. Ecology, 86(2): 288-297.

Mace J E, Amrhein C. 1999. Leaching and reclamation of a soil irrigated with moderate SAR waters. Soil Science Society of America Journal, 65(1): 199-204.

Marshall T J, Holmes J W, Rose C W. 1996. Soil Physics ( ${ }^{\text {rd }}$ ed.). Cambridge: Cambridge University Press, 92-96.

Matula S. 2003. The influence of tillage treatments on water infiltration into soil profile. Plant, Soil and Environment, 49(7): 298-306.

Melvis E G. 2001. Landuse and Water Resources in Temperate and Tropical Climates. Cambridge: Cambridge University, 144-146.

Michaelides K, Lister D, Wainwright J, et al. 2009. Vegetation controls on small-scale runoff and erosion dynamics in a degrading dryland environment. Hydrological Processes, 23(11): 1617-1630.

Munshower F F. 1994. Practical Handbook of Disturbed Land Revegetation. Boca Raton, FL: Lewis Publishers.

Murray C D, Buttle J M. 2005. Infiltration and soil water mixing on forested and harvested slopes during spring snowmelt, Turkey Lakes Watershed, Central Ontario. Journal of Hydrology, 306(1-4): 1-20.

Ni H B, Zhang L P, Zhang D R, et al. 2008. Weathering of Pisha-sandstones in the wind-water erosion crisscross region on the Loess Plateau. Journal of Mountain Science, 5(4): 340-349.

Patel M S, Singh N T. 1981. Changes in bulk density and water intake rate of a coarse textured soil in relation to different levels of compaction. Journal of the Indian Society of Soil Science, 29(1): 110-112.

Philip J R. 1957. The theory of infiltration: 4. sorptivity and algebraic infiltration equations. Soil Science, 84(3): $257-264$.

Qian N, Wang K Q, Yan L D, et al. 1980. Effects of coarse sediment source region in the middle Yellow River on scour and siltation in the lower Yellow River. In: First International Academic Conference Proceedings on the River and Sediment. Beijing: Guanghua School Press, 33-62. (in Chinese)

Ran D C, Liu L W, Zhao L Y. 2000. Change in Soil and Water Conservation, Sediment and Water in the Region from He-Kou-Zhen to Long-Men in the Middle Yellow River. Zhengzhou: The Yellow River Water Conservancy Press, 12-24. (in Chinese).

Rawls W J, Nemes A, Pachepsky Y A. 2005. Effect of soil organic matter on soil hydraulic properties. In: Pachepsky Y A, Rawls W J. Development of Pedotransfer Functions in Soil Hydrology. Amsterdam: Elsevier, 95-114.

Reynolds B, Reddy K J. 2012. Infiltration rates in reclaimed surface coal mines. Water, Air, \& Soil Pollution, 223(9): 5941-5958.

Senigagliesi C, Ferrari M. 1993. Soil and crop responses to alternative tillage practices. In: Buxton D R, Shibles R, Forsberg R A, et al. International Crop Science I. Madison, WI: Crop Science Society of America Inc., 27-35.

Shi Y C, Ye H, Hou H B, et al. 2004. The internal cause of the erosion in "Pisha" sandstone area, southern Inner Mongolia. Acta Geoscientica Sinica, 25(6): 659-664. (in Chinese)

Shougrakpam S, Sarkar R, Dutta S. 2010. An experimental investigation to characterise soil macroporosity under different land use and land covers of northeast India. Journal of Earth System Science, 119(5): 655-674.

Shrestha G, Stahl P D, Ingram L. 2005. Influence of reclamation management practices on soil bulk density and infiltration rates on surface coal mine lands in Wyoming. Presented at 2005 National Meeting of the American Society of Mining and Reclamation, Breckenridge, CO.

Smith R E, Woolhiser D A. 1971. Overland flow on an infiltrating surface. Water Resources Research, 7(4): 899-913.

Stahl P D, Perryman B L, Sharmasarkar S, et al. 2002. Stockpiling vs. exposure to traffic: best management of topsoil on in-situ uranium wellfields. Restoration Ecology, 10: 129-137.

Sun J Z. 2005. Loessology. Hong Kong: Hong Kong Archaeological Society, 30-61. (in Chinese)

Taboada M A, Micucci F G, Cosentino D J, et al. 1998. Comparison of compaction induced by conventional and zero tillage in two soils of the Rolling Pampa of Argentina. Soil and Tillage Research, 49(1-2): 57-63. 
Thien S J. 1979. A flow diagram for teaching texture by feel analysis. Journal of Agronomic Education, 8: 54-55.

Tisdall J M, Adem H H. 1986. Effect of water content of soil at tillage on size-distribution of aggregates and infiltration. Australian Journal of Experimental Agriculture, 26(2): 193-195.

Walkley A, Black I A. 1934. An examination of the degtjareff method for determining soil organic matter, and a proposed modification of the chromic acid titration method. Soil Science, 37(1): 29-38.

Wang X. 2000. Study of sediment source of small watershed in Pisha rock area. Soil and Water Conservation in China, (4): 17-18. (in Chinese)

Wang T J, Wedin D, Zlotnik V A. 2009. Field evidence of a negative correlation between saturated hydraulic conductivity and soil carbon in a sandy soil. Water Resources Research, 45, W07503, doi: 10.1029/2008WR006865.

Yang F S, Cao M M, Li H E, et al. 2013. Simulation of sediment retention effects of the single seabuckthorn flexible dam in the Pisha sandstone area. Ecological Engineering, 52: 228-237.

Ye H, Shi J S, Chen Y P, et al. 2004. A new method based on GPS and GIS for quantitative assessment of gravity erosion in Pi-sandstone area. Acta Geoscientica Sinica, 25(4): 479-482. (in Chinese)

Ye H, Shi J S, Li X Q, et al. 2006. The effect of soft rock lithology upon its Anti-erodibility. Acta Geoscientica Sinica, 27(2): 145-150. (in Chinese) 